\title{
Pengalaman ibu primipara dengan riwayat sectio caesarea dalam pemberian Air Susu Ibu (ASI): scoping review
}

\author{
Dwi Margareta Andini ${ }^{1 *}$, Andari Wuri Astuti ${ }^{2}$, Fitria Siswi Utami ${ }^{3}$ \\ ${ }^{1}$ Mahasiswa Magister IImu Kebidanan, Fakultas IImu Kesehatan, Universitas 'Aisyiyah Yogyakarta, Indonesia. \\ 2, 3 Dosen Magister IImu Kebidanan, Fakultas IImu Kesehatan, Universitas 'Aisyiyah Yogyakarta, Indonesia.
}

\section{INFORMASI ARTIKEL:}

\begin{tabular}{l}
\hline Riwayat Artikel: \\
Tanggal diterima 15 April 2019 \\
Tanggal di revisi 30 Mei 2019 \\
Tanggal di Publikasi 30 Juni 2019 \\
\hline Kata kunci: \\
Pengalaman, \\
Ibu melahirkan, \\
Pemberian ASI, \\
Sectio Caesarea
\end{tabular}

10.32536/jrki.v3i1.40

Keyword:

Experience, Maternall, Breastfeed, Sectio Caesaea.

\begin{abstract}
ABSTRAK
Latar belakang: Badan Kesehatan Dunia pada tahun 2018 melaporkan bahwa rata-rata angka pemberian ASI eksklusif di dunia adalah $38 \%$ sementara target cakupan pemberian ASI yakni $80 \%$. Ibu primipara mempunyai resiko lebih tinggi mengalami kesulitan pada pemberian Air Susu Ibu (ASI) dikarenakan minimnya pengalaman dan persiapan menjadi ibu. Selain faktor primipara, jenis persalinan juga mempengaruhi keberhasilan menyusui secara eksklusif. Ibu dengan post secarean section mempunyai resiko lebih tinggi untuk tidak memberikan ASI eksklusif pada bayinya karena adanya hambatan rasa nyeri dan ketidaknyamanan baik secara fisik maupun emosional. Tujuan penelitian: Untuk melihat gambaran pengalaman ibu dalam melakukan praktik menyusui pada ibu dengan persalinan cesarean section Metode: Metode yang digunakan adalah scoping review yang terdiri dari 5 tahapan, yaitu: melakukan focusing review dengan framework PEOS (Population, Exposure, Outcome dan Study Design), melakukan literature searching menggunakan databases yang relevan. Menyeleksi studi yang relevan menggunakan kriteria inklusi dan ekslusi; melakukan critical appraisal untuk menilai kualitas literature, melakukan data extraksi, menganalisis dan melaporkan hasil. PRISMA Flowchart (Preferred Reporting Items for Systematic reviews and Meta-Analyses), digunakan untuk menggambarkan alur pencarian literature. Hasil : 6 literature terseleksi dan mempunyai Grade A dan B. Dua tema muncul sebagai hasil dari scoping review yaitu faktor yang mempengaruhi dalam pemberian ASI dan dampak tidak melakukan IMD untuk keberlangsungan pemberian ASI. Simpulan: Faktor yang mempengaruhi dalam keberhasilan pemberian ASI yakni jenis persalinan, Inisiasi Menyusui Dini, pengalaman menyusui sebelumnya, kebijakan rumah sakit, paritas, tenaga kesehatan, pengetahuan ibu, dukungan orang terdekat, komplikasi selama persalinan, self efficacy, Budaya dan anggapan masyarakat. Persalinan cesarean section berdampak pada proses laktogenesis II tertunda.
\end{abstract}

Background: WHO 2018 reported only 38\% babies have breastfed exlusively, whilst the target is $80 \%$. Evidence reveal that primiparous women have higher risk for having difficulties for practicing breastfeeding compare to women who experienced parenting before. Additionally, women with post section secarean also have barriers on practicing breasfeeding due to feeling pain and discomfort after section sectarian. Study Aim: This study aimed to explore breastfeeding practice and experiences amongst women after cesarean section. Methods: Scoping review was applied in this study which involved the steps; focusing review by using PEOS (Population, Exposure, Outcome dan Study Design) framework, literature search in relevant databases, applied inclusion and exclusion criteria to selected relevant studies, critical appraisal to assess quality of selected studies; data extraction; analyzing and data reporting. PRISMA Flowchart (Preferred Reporting Items for Systematic reviews and MetaAnalyses) was used to describes the steps from searching liteartures until studies inclusion. Result: 6 studies with Grade A and B included for review. Two themes emerged which are factors influencing exclusive berastfeeding and outcome of not practicing exclusive breastfeeding. Conclusion: Factors that influence the success of breastfeeding are the type of labor, Early Breastfeeding Initiation, previous breastfeeding experience, hospital policy, parity, health personnel, maternal knowledge, support of the closest person, complications during labor, self efficacy, culture and public opinion. Cesarean section labor has a delayed effect on the process of lactogenesis II. 


\section{Pendahuluan}

World Breastfeeding Week (WBW) tahun 2018 menyatakan bahwa dari 136.700 .000 bayi yang dilahirkan diseluruh dunia, hanya $32,6 \%$ yang mendapat Air Susu Ibu (ASI) secara eksklusif pada usia 0 sampai 6 bulan pertama. Data World Health Organization (WHO) 2018 juga menyebutkan bahwa rata-rata angka pemberian ASI eksklusif di dunia hanya (38\%), sedangkan target WHO adalah cakupan pemberian ASI yaitu $80 \%$. Salah satu kebijakan pemerintah untuk meningkatkan cakupan ASI ekslusif diantaranya yaitu adanya Peraturan Pemerintah Republik Indonesia Nomor 33 Tahun 2012 tentang Pemberian ASI secara eksklusif pada bayi di Indonesia. Kebijakan tersebut mengatur berbagai hal terkait pemberian ASI secara eksklusif termasuk upaya strategis peningkatan cakupan ASI eksklusif melalui penerapan 10 Langkah Menuju Keberhasilan Menyusui (LMKM) diseluruh fasilitas pelayanan kesehatan (IDAI, 2013). Program 10 LMKM telah dicanangkan oleh WHO sejak 1989 dan telah direkomendasikan oleh United Nations Children's Fund (UNICEF) sebagai gold standard yang efektif meningkatkan pemberian ASI eksklusif. Agboado et al (2010) dan Hauck et al (2011) yang melaporkan bahwa ibu dengan primipara lebih mungkin untuk tidak memberikan ASI secara eksklusif karena belum mempunyai pengalaman. Selain faktor primipara, jenis persalinan juga mempengaruhi keberhasilan menyusui secara eksklusif. Ibu dengan post sectio secarea mempunyai resiko tidak memberikan ASI eksklusif pada bayinya. Ibu dengan post sectio caesarea akan merasakan ketidaknyamanan baik secara fisik maupun emosional. Rasa sakit yang dirasakan ibu juga akan membatasi interaksi antara ibu dan bayi serta akan menyebabkan ibu enggan untuk menyusui bayinya. (Thobeka, et al, 2018).

* Korespondensi penulis.

Alamat E-mail: dini margaretha@yahoo.co.id

\section{Metode penelitian}

Metode yang digunakan yakni scoping review. Scoping review merupakan tinjauan sistematis yang dapat digunakan untuk menginterpretasikan hasil dengan berbasis bukti untuk memetakan konsep yang mendasari area penelitian, sumber bukti, dan jenis bukti yang tersedia (Tricco et al., 2016). Ulasan ini menggunakan metodologi untuk peninjauan pengelompokan seperti yang disarankan oleh Arksey dan O'Malley (2005) dan dikembangkan lebih lanjut oleh Levac et al (2010). Ada empat alasan untuk melakukan scoping review : (1) untuk memeriksa jangkauan dan sifat kegiatan penelitian, (2) untuk menentukan nilai melakukan tinjauan sistematis penuh. (3) untuk meringkas dan menyebarluaskan temuan penelitian, dan (4) untuk mengidentifikasi kesenjangan penelitian dalam literatur yang ada.

Adapun tahapan yang dilakukan dalam ulasan scoping ini terdiri dari : (1) mengidentifikasi fokus review, (2) mengembangkan fokus review dan strategi pencarian menggunakan format PEOS (Population, Exposure, Outcome dan Study Design), (3) mengidentifikasi studi yang relevan, (4) Memetakan data menggunakan PRISMA Flowchart (Preferred Reporting Items for Systematic reviews and Meta-Analyses) (5) Data Extraction dengan menyusun, meringkas dan melaporkan hasil dan pembahasannya.

Langkah 1: Mengidentifikasi fokus review

Tinjauan ini dipandu oleh pertanyaan "Bagaimana pengalaman ibu dengan riwayat sectio caesarea dalam pemberian ASI?". Untuk keperluan penelitian ini, tinjauan literatur didefinisikan sebagai sintesis penelitian yang bertujuan untuk memetakan literatur pada topik pengalaman ibu dengan riwayat sectio caesarea dalam pemberian ASI dan mengidentifikasi konsep-konsep kunci, kesenjangan dalam penelitian, dan sebagai sumber bukti untuk menginformasikan praktik, kebijakan, dan penelitian tentang pemberian ASI. (Pham et al, 2014). 
Langkah 2: Mengembangkan fokus review menggunakan PEOS

Dalam mengembangkan fokus review dan strategi pencarian, peneliti menggunakan format Population, Exposure, Outcome, dan Study Design (PEOS) dalam mengelola dan memecahkan fokus review (Tabel 1). Penggunaan PEOS membantu dalam mengidentifikasi konsep-konsep kunci dalam fokus review, mengembangkan istilah pencarian yang sesuai untuk menggambarkan masalah, dan menentukan kriteria inklusi dan eksklusi. Fokus pencarian artikel adalah penelitian kualitatif, sehingga PEOS dinilai tepat untuk digunakan (Bettany-Saltikov., 2012).

\begin{tabular}{|c|c|c|c|}
\hline $\begin{array}{l}\text { Population } \\
\text { and their } \\
\text { problems }\end{array}$ & Exposure & $\begin{array}{l}\text { Outcomes } \\
\text { or Themes }\end{array}$ & Study Design \\
\hline $\begin{array}{l}\text { - Wome } \\
\text { - Women's } \\
\text { - Maternal } \\
\text { - Mother } \\
\text { - Mother } \\
\text { - Mothers' }\end{array}$ & $\begin{array}{ll}\text { - } & \text { Lactating } \\
\text { - } & \text { Breastfeeding } \\
\text { - } & \text { Initiation } \\
\text { - } & \text { Exclusive } \\
& \text { breastfeeding } \\
\text { - } & \text { Infant } \\
& \text { breastfeedin } \\
\text { - } & \text { Breastfeed }\end{array}$ & $\begin{array}{l}\text { - Experience } \\
\text { - Opinion } \\
\text { - View } \\
\text { - Perspective }\end{array}$ & $\begin{array}{l}\text { All research } \\
\text { studies / } \\
\text { study design } \\
\text { related the } \\
\text { experience of } \\
\text { mothers in } \\
\text { exclusive } \\
\text { breastfeedin } \\
g\end{array}$ \\
\hline
\end{tabular}

Tabel 1. Framework PEOS

Langkah 3: Mengidentifikasi studi yang relevan

Strategi pencarian artikel dikembangkan menggunakan beberapa data base dan grey literature. Adapun data base yang digunakan adalah Pubmed, Proquest, Wiley, Science Direct dan Website yang digunakan untuk mencari grey literature yakni WHO, KEMENKES RI dan Google scholar.

Data disaring sesuai dengan kriteria yang peneliti tentukan. Proses penyaringan data yaitu menggunakan PRISMA Flowchart. PRISMA merupakan Preferred Reporting Items for Systematic reviews and Meta-Analyses, dikembangkan untuk membantu penulis dalam melaporkan Sistematic Reviews (SR) dan MetaAnalyses (MA). (Peters et al, 2015). Adapun tahaptahan penyaringan data disajikan pada gambar 1 .

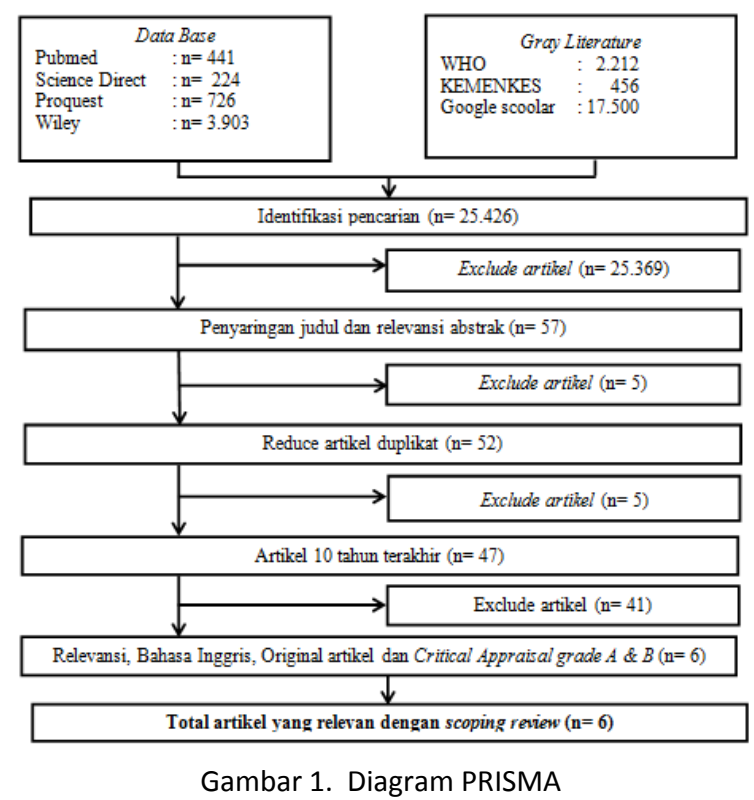

Langkah 4: Memetakan Data

Data dari 6 artikel diekstraksi untuk memasukkan kriteria kunci seperti lokasi penelitian, populasi penelitian, tujuan penelitian, metodologi, dan temuan atau rekomendasi yang signifikan. Penulis secara independen mencatat informasi dan kemudian membandingkan data yang di ekstrak. Penulispun melakukan konsultasi dengan pembimbing sampai semua konten di analisis dan menjadi tema.

Langkah 5: Menyusun, meringkas dan melaporkan hasil dan pembahasannya

Sama halnya dengan yang dilakukan Levac et al 2010, penulis melakukan pendekatan tiga fase untuk menyusun, meringkas, dan melaporkan hasil. Pertama, analisis numerik deskriptif disediakan yang mencakup jumlah artikel, tahun publikasi, dan jenis studi. Kedua, kekuatan dan kelemahan dalam literatur yang diidentifikasi melalui analisis tematik dari studi yang disertakan dalam laporan. Fase akhir tahap ini adalah peninjauan implikasi temuan dalam kaitannya dengan penelitian, praktik dan kebijakan dimasa depan. 


\begin{tabular}{|c|c|c|c|c|c|c|c|c|c|c|c|}
\hline No & $\begin{array}{l}\text { Penulis, } \\
\text { Tahun, } \\
\text { Judul, } \\
\text { Tempat }\end{array}$ & & Tujuan & Desain & $\begin{array}{c}\text { Pengumpulan } \\
\text { data }\end{array}$ & $\begin{array}{l}\text { Informan dan } \\
\text { Rekrutmen }\end{array}$ & & Tema & & Hasil & Grade \\
\hline 1 & $\begin{array}{l}\text { Chaplin et } \\
\text { al., } 2016 \\
\text { Maternal } \\
\text { perceptions } \\
\text { of } \\
\text { breastfeedi } \\
\text { ng difficulty } \\
\text { after } \\
\text { caesarean } \\
\text { section } \\
\text { with } \\
\text { regional } \\
\text { anaesthesia } \\
\text { : A } \\
\text { qualitative } \\
\text { study } \\
\text { Australia }\end{array}$ & 1. & $\begin{array}{l}\text { Mengumpulkan } \\
\text { data kualitatif } \\
\text { tentang faktor- } \\
\text { faktor penyulit } \\
\text { dalam } \\
\text { pemberian ASI } \\
\text { pasca sectio } \\
\text { caesarea } \\
\text { Menguji } \\
\text { tentang sectio } \\
\text { caesarea } \\
\text { dengan } \\
\text { menggunakan } \\
\text { anastesi } \\
\text { regional dapat } \\
\text { menyebabkan } \\
\text { kesulitan } \\
\text { menyusui serta } \\
\text { terhambatnya } \\
\text { produksi ASI }\end{array}$ & Kualitatif & $\begin{array}{l}\text { 1. Fokus } \\
\text { Group } \\
\text { Discussion } \\
\text { (FGD) } \\
(\mathrm{n}=8) \\
\text { 2. Wawancar } \\
\text { a semi- } \\
\text { structured }\end{array}$ & $\begin{array}{l}\text { 1. Ibu yang dirujuk ke } \\
\text { poli bagian } \\
\text { Breastfeeding } \\
\text { support center } \\
\text { dengan diagnosa } \\
\text { penyulit menyusi } \\
\text { setelah } \\
\text { pelaksanaan } \\
\text { operasi sesar. } \\
\text { 2. Ibu muda usia } \leq 18 \\
\text { tahun } \\
\text { 3. Suami dari ibu } \\
\text { menyusui pasca } \\
\text { operasi sesar }\end{array}$ & 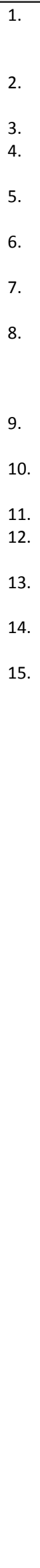 & $\begin{array}{l}\text { Ketidaknyaman } \\
\text { an menghadapi } \\
\text { persalinan SC } \\
\text { Penurunan } \\
\text { kesadaran } \\
\text { Cemas } \\
\text { Bounding Skin } \\
\text { to Skin } \\
\text { Intuisi yang } \\
\text { terganggu } \\
\text { Terlalu } \\
\text { mengantuk } \\
\text { Dukungan ibu } \\
\text { lain } \\
\text { Anggapan } \\
\text { kolostrum / ASI } \\
\text { tidak } \\
\text { mencukupi } \\
\text { Pemasok susu } \\
\text { formula } \\
\text { Pusing, mual, } \\
\text { cemas } \\
\text { Depresi } \\
\text { Jarak ibu dan } \\
\text { bayi } \\
\text { Tidak ada reflek } \\
\text { menyusui bayi } \\
\text { Kurangnya } \\
\text { informasi } \\
\text { Beban kerja } \\
\text { tenaga } \\
\text { kesehatan } \\
\text { aini }\end{array}$ & 5. & 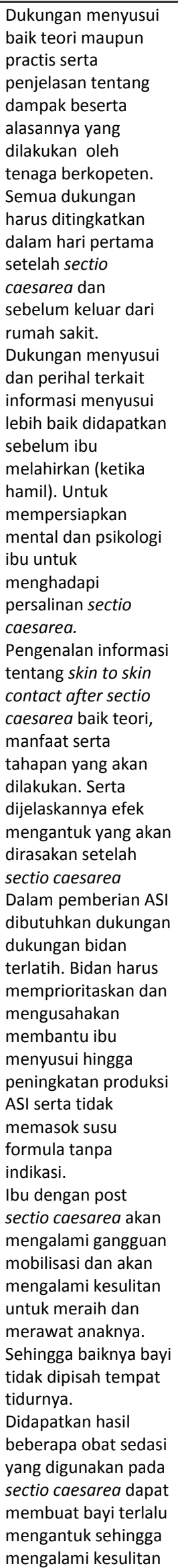 & $A$ \\
\hline
\end{tabular}


untuk menempel

pada payudara

7. Kurangnya waktu IMD

(Inisiasi menyusu

dini). Kontak kulit

segera setelah lahir

mendorong

pelepasan oksitosin

yang menjadi hal

berpengaruh dalam

produksi ASI.

8. Ibu dengan jenis

persalinan sectio

caesarea

membutuhkan lebih

banyak waktu dan

dukungan bidan

untuk membantu

proses menyusui

tetapi bidan terlalu

sibuk karena tidak

memadai

kepegawaian

9. pascanatal post bedah.

10. Persepsi ibu, tersedianya pasokan suplemen pengganti formula, bidan yang tidak dapat selalu ada untuk membimbing menyebabkan durasi menyusui pendek atau bahkan penghentian menyusui seluruhnya. Dari kesulitankesulitan ini dan perasaan yang luar biasa serta

kekecewaan yang dialami beresiko menyebabkan depresi postpartum.

\begin{tabular}{|c|c|c|c|c|c|c|c|c|c|c|c|}
\hline 2 & $\begin{array}{l}\text { Tokat et al., } \\
2015 \\
\text { Early } \\
\text { postpartum } \\
\text { breastfeedi } \\
\text { ng } \\
\text { outcomes } \\
\text { and } \\
\text { breastfeedi } \\
\text { ng self- } \\
\text { efficacy in } \\
\text { Turkish } \\
\text { mothers } \\
\text { undergoing } \\
\text { vaginal } \\
\text { birth or } \\
\text { cesarean } \\
\text { birth with } \\
\text { different } \\
\text { types of } \\
\text { Anasthesia } \\
\text { Turkey }\end{array}$ & $\begin{array}{l}\text { Membandingkan } \\
\text { hasil proses } \\
\text { menyusui dan } \\
\text { kemandirian } \\
\text { menyusui pada ibu } \\
\text { dengan jenis } \\
\text { persalinan } \\
\text { pervaginam dan } \\
\text { persalinan sectio } \\
\text { caesarea }\end{array}$ & $\begin{array}{l}\text { Kuantitat } \\
\text { if }\end{array}$ & & $\begin{array}{l}1 . \\
2 . \\
3 . \\
4 . \\
5 .\end{array}$ & $\begin{array}{l}\text { Ibu usia } 18 \text { tahun } \\
\text { atau lebih } \\
\text { Memiliki } \\
\text { kemampuan } \\
\text { berbahasa. } \\
\text { Memiliki } \\
\text { keinginan } \\
\text { menyusui bayinya } \\
\text { Kehamilan aterm } \\
\text { Dan bayi baru } \\
\text { lahir sehat dan } \\
\text { tanpa cacat } \\
\text { bawaan } \\
\text { man direkrut } \\
\text { san menggunakan } \\
\text { sampling }\end{array}$ & 2. & $\begin{array}{l}\text { Pengalaman } \\
\text { menyusui } \\
\text { Kemandirian } \\
\text { ibu dalam } \\
\text { menyusui }\end{array}$ & 2. & $\begin{array}{l}\text { Ibu yang melahirkan } \\
\text { dengan sectio } \\
\text { caesarea terutama } \\
\text { jika menggunakan } \\
\text { anastesi umum, } \\
\text { mereka mengalami } \\
\text { banyak kesulitan } \\
\text { dalam praktik } \\
\text { menyusui. } \\
\text { Tiga kelompok studi } \\
\text { menunjukkan } \\
\text { keterlambatan pada } \\
\text { inisiasi menyusui dini. } \\
\text { Awal dan sukses } \\
\text { menyusui akan } \\
\text { berdampak pada } \\
\text { keberlangsungan } \\
\text { menyusui } \\
\text { selanjutnya. }\end{array}$ & A \\
\hline 3 & $\begin{array}{l}\text { Koopman } \\
\text { et al., } 2016 \\
\text { Early skin } \\
\text { to skin } \\
\text { contact for }\end{array}$ & $\begin{array}{l}\text { Untuk memberikan } \\
\text { wawasan tentang } \\
\text { faktor-faktor kunci } \\
\text { dari } \\
\text { perspektif dokter }\end{array}$ & Kualitatif & $\begin{array}{l}\text { Wawancara } \\
\text { semi- } \\
\text { structured }\end{array}$ & $\begin{array}{l}\text { Dok } \\
\text { me } \\
\text { keb } \\
\text { gin } \\
\text { dan }\end{array}$ & $\begin{array}{l}\text { er dan tenaga } \\
\text { s dari unit } \\
\text { danan dan } \\
\text { cologi, serta dokter } \\
\text { enaga medis dari }\end{array}$ & 2. & $\begin{array}{l}\text { Early skin to } \\
\text { skin contact } \\
\text { Pengetahuan } \\
\text { tenaga medis } \\
\text { Kebijakan }\end{array}$ & 1. & $\begin{array}{l}\text { Ketidak optimalan } \\
\text { skin to skin } \\
\text { disebabkan karena } \\
\text { kebijakan rumah } \\
\text { sakit, faktor keluarga, }\end{array}$ & A \\
\hline
\end{tabular}




\begin{tabular}{|c|c|c|c|c|c|c|c|c|c|c|}
\hline & $\begin{array}{l}\text { healthy full- } \\
\text { term } \\
\text { infants } \\
\text { after } \\
\text { vaginal and } \\
\text { caesar } \\
\text { delivery : a } \\
\text { qualitative } \\
\text { study }\end{array}$ & $\begin{array}{l}\text { yang mempengaruhi } \\
\text { kontak kulit ke kulit } \\
\text { awal setelah } \\
\text { persalinan } \\
\text { pervaginam dan } \\
\text { sesar. }\end{array}$ & & & $\begin{array}{l}\text { unit perawatan intensif } \\
\text { neonatal. }\end{array}$ & $\begin{array}{l}4 . \\
5 .\end{array}$ & $\begin{array}{l}\text { Rumah Sakit } \\
\text { Faktor keluarga } \\
\text { Pelaksanaan }\end{array}$ & $\begin{array}{l}2 . \\
3 .\end{array}$ & $\begin{array}{l}\text { tim pelaksanaan } \\
\text { Pengetahuan tenaga } \\
\text { kesehatan dan } \\
\text { keluarga berperan } \\
\text { penting dalam } \\
\text { pelaksanaan IMD } \\
\text { IMD lebih sulit } \\
\text { dilakukan pada pasien } \\
\text { pasca sectio caesarea } \\
\text { dikarenakan beban } \\
\text { kerja dan jumlah staff } \\
\text { yang terbatas }\end{array}$ & \\
\hline 4 & $\begin{array}{l}\text { Zanardo et } \\
\text { al., } 2010 \\
\text { Elective } \\
\text { cesarean } \\
\text { delivery : } \\
\text { does it have } \\
\text { a negative } \\
\text { effect on } \\
\text { breastfeedi } \\
\text { ng? }\end{array}$ & $\begin{array}{l}\text { Untuk mengevaluasi } \\
\text { tingkat menyusui, } \\
\text { didefinisikan sesuai } \\
\text { dengan pedoman } \\
\text { organisasi } \\
\text { kesehatan dunia, } \\
\text { dari kehamilan usia } \\
6 \text { bulan sampai } \\
\text { engan pasca } \\
\text { persalinan bayi }\end{array}$ & $\begin{array}{l}\text { Kuantitat } \\
\text { if }\end{array}$ & $\begin{array}{l}\text { Kohort } \\
\text { Prospektif }\end{array}$ & $\begin{array}{l}\text { bayi baru lahir dengan } \\
\text { SC }\end{array}$ & $\begin{array}{l}1 . \\
2 . \\
3 . \\
4 .\end{array}$ & $\begin{array}{l}\text { Elective Sectio } \\
\text { caesarean } \\
\text { Emergency } \\
\text { Sectio } \\
\text { caesarean } \\
\text { Vaginal Delivery } \\
\text { Breastfeeding }\end{array}$ & \multicolumn{2}{|c|}{$\begin{array}{l}\text { Hasil menyusui di ruang } \\
\text { bersalin secara signifikan } \\
\text { lebih tinggi pada persalinan } \\
\text { pervaginam dibandingkan } \\
\text { dengan post SC }(71,5 \% \text { vs } \\
3,5 \%, p<0,0001)\end{array}$} & $A$ \\
\hline 5 & $\begin{array}{l}\text { A Karlstrom } \\
\text { et al, } 2013 \\
\text { Maternal } \\
\text { and infant } \\
\text { outcome } \\
\text { after } \\
\text { caesarean } \\
\text { section } \\
\text { without } \\
\text { recorded } \\
\text { medical } \\
\text { indication: } \\
\text { finding } \\
\text { from a } \\
\text { swedish } \\
\text { case- } \\
\text { control } \\
\text { study }\end{array}$ & $\begin{array}{l}\text { Membandingkan } \\
\text { komplikasi / } \\
\text { kesulitan menyusui } \\
\text { yang terjadi antara } \\
\text { ibu yang melahirkan } \\
\text { pervaginam dan ibu } \\
\text { yang sectio caesarea }\end{array}$ & $\begin{array}{l}\text { Kuantitat } \\
\text { if }\end{array}$ & $\begin{array}{l}\text { Case control } \\
\text { menggunaka } \\
\mathrm{n} \text { daftar } \\
\text { rekam medis. }\end{array}$ & $\begin{array}{l}\text { Ibu dengan riwayat } \\
\text { sectio caesarea dan } \\
\text { pervaginan tanpa } \\
\text { indikasi }\end{array}$ & $\begin{array}{l}1 . \\
2 .\end{array}$ & $\begin{array}{l}\text { Breastfeeding } \\
\text { Sectio caesarea }\end{array}$ & \multicolumn{2}{|c|}{$\begin{array}{l}\text { Komplikasi/ kesulitan } \\
\text { menyusui pada ibu dengan } \\
\text { sectio caesareae elective } \\
\text { sebesar OR } 6,8 \text { ( } 95 \% \mathrm{Cl} 3,2 \text { - } \\
14,5)\end{array}$} & A \\
\hline 6 & $\begin{array}{l}\text { David } \\
\text { Mukunya, } \\
\text { et al } 2017 \\
\text { Factors } \\
\text { associated } \\
\text { with } \\
\text { delayed } \\
\text { initiation of } \\
\text { breastfeedi } \\
\text { ng }\end{array}$ & $\begin{array}{l}\text { Untuk menentukan } \\
\text { prevalensi dan } \\
\text { faktor-faktor yang } \\
\text { berhubungan } \\
\text { dengan } \\
\text { keterlambatan } \\
\text { inisiasi menyusui }\end{array}$ & $\begin{array}{l}\text { Kuantitat } \\
\text { if }\end{array}$ & $\begin{array}{l}\text { Regresi } \\
\text { logistik } \\
\text { multivariabel }\end{array}$ & $\begin{array}{l}\text { Ibu dari anak usia <2 } \\
\text { tahun }\end{array}$ & $\begin{array}{l}3 . \\
4 . \\
5 . \\
6 . \\
7 . \\
8 . \\
9 . \\
10 .\end{array}$ & $\begin{array}{l}\text { Status } \\
\text { Pendidikan } \\
\text { Penundaan } \\
\text { Inisiasi } \\
\text { Menyusui Dini } \\
\text { (IMD) } \\
\text { Faktor IMD } \\
\text { Letak bayi } \\
\text { Persalinan } \\
\text { sectio caesarea } \\
\text { Membuang ASI } \\
\text { awal } \\
\text { Komplikasi } \\
\text { persalinan } \\
\text { Keinginan ibu } \\
\text { Bantuan orang } \\
\text { lain } \\
\text { Persalinan } \\
\text { dirumah }\end{array}$ & $\begin{array}{l}1 . \\
2 .\end{array}$ & $\begin{array}{l}\text { Hampir setengah dari } \\
\text { sample ibu menunda } \\
\text { inisiasi menyusui } \\
\text { Dibutuhkan program } \\
\text { promosi IMD }\end{array}$ & $A$ \\
\hline
\end{tabular}




\section{Hasil dan Pembahasan}

Review ini untuk mengeksplorasi pengalaman ibu dengan riwayat sectio caesarea dalam pemberian ASI dan mengumpulkan data tentang faktor dan orang yang terlibat dalam konteks pemberian ASI eksklusif.

\section{Jenis Persalinan}

Jenis persalinan pada ibu memiliki pengaruh terhadap pemberian ASI secara eksklusif. Persalinan secara sectio caesarea akan memiliki kendala menyusui diawal setelah persalinan. Terutama jika diawal jam setelah bayi lahir. Bagi ibu yang diberikan anestesi karena kesadaran ibu belum pulih sepenuhnya. Periode awal setelah bayi lahir merupakan periode yang menentukan keberhasilan dalam menyusui selanjutnya (Dachew and Bifftu, 2014; Elyas et al., 2017).

Proses persalinan secara sectio caesarea dapat mencegah kesakitan pada ibu karena tidak dilakukan secara pervaginam. Akan tetapi juga memiliki risiko bayi lebih tinggi untuk tidak disusui oleh ibunya dibandingkan dengan bayi yang lahir secara pervaginam. Hal ini disebabkan karena kondisi ibu yang melahirkan secara sectio caesarea merasakan nyeri dan akan merasakan kesulitan untuk menyusui bayinya, serta keterlambatan dalam melakukan inisiasi menyusui dini yang akan menimbulkan penurunan sekresi prolaktin (Bodner et al., 2011; Senarath et al., 2011; Alves et al., 2013).

\section{Inisiasi Menyusu Dini (IMD)}

Hasil review menunjukkan bahwa persepsi tentang Inisiasi Menyusu Dini (IMD) adalah penting dan bermanfaat meskipun banyak perbedaan tentang sejauh mana tentang IMD dipraktikkan di rumah sakit. IMD telah banyak dideskripsikan namun tenaga kesehatan memiliki pemahaman yang bervariasi dan kadang-kadang salah mengartikan IMD, sebagai contoh tenaga kesehatan mendeskripsikan IMD dilakukan kurang dari setengah jam, sedangkan yang direkomendisaikan ialah 1 jam segera setelah kelahiran. Selanjutnya bayi kadang-kadang dibawa ke inkubator untuk menyelesaikan prosedur rutin sehingga IMD dianggap menjadi penghambat dalam penatalaksanaan bayi baru lahir, terutama untuk persalinan sectio caesarea IMD jarang dilaksanakan. (Koopman et al., 2016)

Pemberian ASI sangat penting diberikan selama 24 jam pertama setelah bayi lahir. Hal ini akan menentukan keberhasilan menyusui selanjutnya. Jika ibu tidak mulai memberikan ASI lebih dari dua hari setelah postpartum, respons pengeluaran prolaktin akan sangat menurun. Kondisi ini biasanya terjadi pada ibu dengan persalinan secara sectio caesarea. Pemberian ASI pada ibu dengan sectio caesarea sebenarnya dapat langsung dilakukan karena operasi dilakukan dengan anestesi spina atau epidural sehingga ibu tetap sadar. Posisi menyusui juga dapat dikondisikan sesuai dengan kondisi ibu. Sehingga proses sectio caesarea tidak bisa dijadikan penghalang untuk tidak 6 menyusui bayi. (IDAI, 2010).

Dalam kelompok penelitian menunjukkan penundaan waktu pertama menyusui. Penting di evaluasi di masa depan adanya pelatihan dan pengawasan dalam setiap pelayanan fasilitas kesehatan dan membangun kesadaran tenaga kesehatan untuk selalu memfasilitasi dalam proses menyusui segera setelah kelahiran, hal ini akan sangat mempengaruhi secara positif hasil menyusui. Keberhasilan menyusui awal akan mempengaruhi kelanjutan menyusui selanjutnya (Alves AL, 2013)

Hasil penelitian dengan menggali pengalaman ibu post sectio caesarea dalam menyusui menyebutkan pada ibu dengan post sectio caesar mengalami laktogenesis II tertunda dilaporkan $30 \%$ wanita dan $44 \%$ menganggap suplai ASI menurun. (Thobeka P, 2018).

\section{Pengalaman menyusui sebelumnya}

Hasil penelitian menjelaskan bahwa pengalaman pribadi seringkali merupakan sumber yang cepat dan kuat terhadap keberhasilan menyusui, dan juga meningkatkan self efficacy menyusui yang lebih tinggi secara signifikan dari pada mereka yang belum memiliki pengalaman. 
Penelitian ini menemukan bahwa wanita yang memiliki pengalaman menyusui sebelumnya memiliki keberhasilan untuk menyusui bayinya secara eksklusif daripada mereka yang belum memiliki pengalaman sebelumnya (Ly Thi Hai Ngo, 2018).

\section{Paritas}

Paritas merupakan jumlah anak yang dilahirkan oleh ibu. Seorang ibu hamil yang baru pertama kali melahirkan akan mengalami masalah terkait perawatan pada bayi karena ibu belum memiliki pengalaman yang baik tentang bagaimana cara merawat bayi. Begitu pula dengan pemberian ASI eksklusif. Apabila ibu mendapatkan pengalaman yang kurang baik dari orang lain tentang pemberian ASI dapat menyebabkan ibu mengalami keraguan dalam pelaksanaan pemberian ASI (Sinta et al., 2017; Arini, 2012).

Ibu multipara memiliki pengaruh positif terhadap pemberian ASI eksklusif dibandingan dengan ibu primipara. Ibu hamil multipara memiliki pengetahuan dari kehamilan sebelum sebelumnya tertuama terkait dengan pemberian ASI. Ibu multipara memiliki pengalaman dari kehamilan sebelum sebelumnya (Lestari et al., 2019; Wardani et al., 2017; Kitano et al., 2016)

\section{Tenaga kesehatan}

Dukungan menyusui baik dari pemberian informasi dan praktik menyusui oleh tenaga kesehatan atau tenaga berkompeten merupakan hal yang sangat dibutuhkan oleh ibu. Dan lebih baik informasi didapatkan dari masa kehamilan untuk persiapan mental dan psikologi ibu menghadapi sectio caesarea dan menyusui setelahnya. (Chaplin, 2016)

Pengetahuan tenaga kesehatan berperan penting dalam keberhasilan pelaksanaan Inisiasi Menyusui Dini (IMD), didalam penelitian juga dijelaskan IMD lebih sulit dilakukan pada pasien pasca sectio caesarea dikarenakan beban kerja dan jumlah staff terbatas (Koopman, 2016)

Hasil literatur menunjukkan bahwa para ibu merasa sangat mengantuk, mual dan tidak berdaya pasca persalinan dengan sectio caesarea, ibu mengalami masalah mobilitas dan kesulitan mengakses dan merawat bayi mereka. Oleh karena itu, bayi harus tetap dengan bayi mereka setelah operasi sectio caesarea. Seperti contoh bayi di letakkan satu tempat tidur dengan ibu. Hasil penelitian menunjukkan bahwa ibu lebih suka menggunakan tempat tidur yang berdampingan dengan bayinya karena memungkinkan ibu yang pasca operasi sesar mudah menjangkau bayinya. (Chaplin, 2016)

\section{Kebijakan Rumah Sakit}

Sejumlah penyedia layanan kesehatan menyoroti fakta bahwa sulit menjangkau pelaksanaan pemberian ASI eksklusif dan Inisiasi Menyusui Dini (IMD) pada ibu post sectio caesarea. Dianggap perlu untuk menegakkan undang-undang yang ada. Mendorong setiap penyelenggara fasilitas pelayanan kesehatan melaksanakan program RS Sayang Ibu dan Bayi sebagai perwujudan nyata PP 33/2012 dan pengaturan iklan sufor, sebagaimana tercantum dalam pasal 19 (e) pelarangan iklan susu formula dan pasokan susu formula di tiap fasilitas layanan.

Kebijakan rumah sakit untuk mendukung dan memfasilitasi tenaga kesehatan untuk bisa melaksanakan IMD pada ibu post sectio caesarea dan pemberian ASI sangat berperan penting dalam tercapainya pelaksanaan pemberian ASI eksklusif. (Koopman, 2016., Chaplin, 2016)

Tempat persalinan dirumah juga dikaitkan dengan IMD yang tertunda, ibu yang melahirkan dirumah lebih cenderung menunda memulai menyusui dibandingkan dengan ibu yang melahirkan di fasilitas kesehatan. Ini bisa terkait dengan kebijakan dan bantuan yang ditawarkan oleh fasilitas kesehatan yang mendorong IMD. Pentingnya adanya orang lain dalam pengambilan keputusan untuk memulai menyusui dan kebutuhan adanya dorongan bagi ibu untuk peran barunya, selain itu konselor ASI di fasilitas kesehatan juga melakukan advokasi kepada tenaga kesehatan lainnya dalam membuat keputusan menyusui. (David Mukunya, et al 2017). 
7. Pengetahuan Ibu

Mendapat informasi yang bertentangan dari tenaga kesehatan adalah masalah yang dijelaskan semua wanita, selain itu kebingungan tentang teknik dan managemen pemberian ASI menimbulkan kecemasan yang lebih lanjut. Beberapa tenaga kesehatan menunjukkan cara melakukan bagaimana cara menyusui namun tenaga kesehatan lainnya memiliki ide yang berbeda-beda sehingga membingungkan ibu dalam pelaksanaannya. Akibat kebingungannya tersebut terhadap informasi yang bertentangan antar tenaga kesehatan maka ibu mencari perencanaan dan arahan kepada konselor ASI di rumah sakit.

Ibu yang memiliki pendidikan tinggi akan memiliki rasa ingin tahu untuk mencari pengalaman yang sebelumnya belum diketahui. Informasi yang diterima akan menjadi pengetahuan. Pengetahuan yang di dapat akan mendorong seseornang melakukan sesuatu tindakan seperti halnya tentang pemberian ASI eksklusif. Promosi dan informasi yang didapat mengenai pemberian ASI eksklusif akan mudah didapat jika ibu memiliki pendidikan tinggi (Sharma and Byrne, 2016; Maastrup et al., 2014)

Pendidikan memiliki pengaruh yang positif dengan pemberian ASI ekslusif. Ibu yang memiliki pendidikan tinggi akan memiliki pengetahuan yang lebih luas dibandingkan dengan ibu dengan pendidikan rendah. Pendidikan juga dapat mendorong seseorang untuk mencari tahu pengalaman yang sebelumnya belum ibu miliki yang kemudian dapat meningkatkan pengetahuan ibu (Alfianrisa et al., 2017; Nisa et al., 2017).

\section{Dukungan untuk Ibu Bekerja}

Dukungan bagi ibu kerja untuk keberlangsungan keberhasilan menyusui dapat berupa beberapa intervensi di lingkungan kerja yang dapat diterapkan seperti program laktasi dilingkungan kerja, meningkatkan kesadaran ibu bekerja akan pentingnya ASI eksklusif, intervensi pribadi seperti : perencanaan dan persiapan pranatal, pembagian tugas dalam pekerjaan serta memfasilitasi Day Care (Taman Penitipan Anak) bagi ibu bekerja yang memiliki anak. (Astuti and Morgan, 2018)

\section{Dukungan orang terdekat}

Dukungan dari keluarga sangat memiliki pengaruh secara langsung terhadap pemberian ASI secara eksklusif. Dukungan keluarga meliputi baik dukungan langsung dari suami maupun dukungan dari keluarga. Ibu yang mendapatkan dukungan yang positif akan lebih memiliki motivasi untuk selalu berusaha memberikan yang terbaik untuk bayinya. Apabila ibu belum mengetahui banyak hal terkait dengan pemberian ASI eksklusif, ibu akan selalu berusaha mencari tahu terkait dengan pemberian ASI secara eksklusif (El-Houfey et al., 2017; Alfanrisa et al., 2017; Atika et al., 2018).

Ibu yang melahirkan secara sectio caesarea sangat memerlukan dukungan, baik dari suami, keluarga, maupun tenaga kesehatan dengan menunjukkan bayi dan memberikan bayi untuk disusui. Hal ini akan membuat ibu merasakan kenyamanan dan akan lebih puas. Inisiasi menyusui dini terbukti meningkatkan keberhasilan dalam praktik menyusui (Kumar et al., 2014; Hung and Berg, 2011).

Penelitian Nickerson, EL (2012) bertujuan menggali pengalaman dukungan suami dalam pelaksanaan praktik menyusui. Wawancara dirancang untuk menggali persepsi ibu tentang peran ayah dalam praktik menyusui, pendidikan dan informasi yang ayah terima tentang praktik menyusui serta persepsi suami dan ibu tentang praktik menyusui. Hasil dari penelitian yakni dukungan praktis dan emosional suami, terutama selama menyusui sangat mempengaruhi keberlangsungan proses menyusui.

Ibu akan merasa lebih mampu dan percaya diri tentang menyusui ketika mereka menganggap bahwa pasangan memiliki dukungan yang baik dan terlibat aktif dalam kegiatan menyusui. Ibu yang kurang mendapat dukungan dari keluarga akan memiiki umpan balik yang negative terkait tentang menyusui serta kurang percaya diri pada kemampuan mereka untuk menyusui, selain dukungan dari keluarga yaitu peran dari tenaga kesehatan juga penting yaitu dengan memberikan 
informasi terkait dengan pemberian ASI dengan melibatkan suami agar suami juga lebih aktif terutama dalam kegiatan yang terkait dengan pemberian ASI (Mannion et al., 2013; Nisa et al., 2017).

\section{Komplikasi dalam Persalinan}

Hasil dari penelitian menjelaskan bahwa salah satu alasan mengapa ibu gagal dalam pelaksanaan Inisiasi Menyusu Dini segera setelah lahir pada ibu dengan pasca caesar adalah karena bayi memiliki masalah kesehatan, seperti gagal bernafas secara spontan, tidak adanya respons terhadap stimulasi, dan beberapa keadaan bayi yang memerlukan tindak lanjut intensif di unit perawatan neonatal. Ibu yang bayinya dipindah ke unit perawatan lebih cenderung berpikir bahwa bayi mereka memiliki masalah kesehatan, ibu ini sangat memperhatikan bayi mereka dan sangat khawatir terhadap bayi mereka, dan cenderung melakukan apapun yang menurut mereka terbaik salah satunya berusaha seoptimal mungkin dapat memberikan ASInya. (Ly Thi Hai Ngo, 2019)

\section{Self Efficacy}

Produksi kolostrum di hari pertama dianggap produksi ASI rendah sehingga ibu merasa tertekan dan memberi bayi mereka susu formula, akan tetapi ada ibu yang menyesal telah memberikan susu formula dan beranggapan bahwa dihari pertama bayi tidak membutuhkan makan yang banyak. Ditemukan bahwa selain kemauan ibu sendiri, susu formula juga diberikan atas saran tenaga kesehatan sebagai suplemen merupakan rekomendasi bidan yang diberikan kepada pasien. Sehingga tenaga kesehatan merusak kepercayaan diri pada kemampua menyusui dan mulai bergantung pada susu formula. (Kiani, 2017)

Dalam sebuah studi menjelaskan, persepsi positif dari operasi caesar dapat menciptakan perasaan yang positif terhadap proses persalinannya. Kemudian perasaan ini dapat meningkatkan keberhasilan untuk menyusui. (Ly Thi Hai Ngo, 2019).

Tema ini mencakup psikologi bahwa wanita menyusui dapat disabotase melalui praktik seperti menawarkan susu formula untuk bayi dihari pertama setelah kelahiran. Ibu dengan kesalahanpahaman beranggapan bahwa kolostrum atau ASI awal yang dihasilkan tidak cukup untuk memenuhi kebutuhan bayinya dan oleh karena itu dibutuhkan formula. Persepsi tentang suplai susu yang sedikit menyebabkan pengenalan susu formula dan hal ini menyebabkan penghentian menyusui dini, ibu merasakan kegagalan dan merasa bersalah terhadap bayinya. depresi terhadap kegagalan menyusui diperparah dengan cara kelahiran mereka yakni dengan cara sectio caesarea. (Chaplin, 2016)

\section{Budaya masyarakat dan anggapan pada ASI awal (Colostrum) \\ Salah satu faktor utama yang terkait} keterlambatan dalam memulai menyusui adalah membuang susu awal (kolostrum). Studi lain juga melaporkan bahwa gagasan budaya yang negatif tentang kolostrum dikaitkan dengan keterlambatan inisiasi menyusui. Tindakan membuang kolostrum disebabkan oleh kesalahpahaman bahwa susu awal adalah susu kotor dan karenanya berbahaya bagi bayi. Membuang ASI awal juga disebabkan oleh faktor bayi sakit dan diharuskan mendapatkan penanganan medis, sehingga untuk mengatasi ketidaknyamanan dan bendungan ASI, ibu membuang ASI awalnya. (Fikawati et al, 2009).

\section{Simpulan}

Peningkatan frekuensi jenis persalinan sectio caesarea terjadi baik di negara maju maupun negara berkembang. Ibu dengan post sectio caesarea menunjukkan proses laktogenesis II tertunda. Beberapa faktor disebutkan menjadi penghambat dalam keberlangsungan proses menyusui, diantaranya jenis persalinan (Sectio Caesarea), pengalaman menyusui, paritas, tenaga kesehatan, kebijakan rumah sakit, pengetahuan ibu, dukungan untuk ibu bekerja, dukungan orang terdekat, komplikasi dalam persalinan, self-efficacy ibu, budaya masyarakat. Selain itu Inisiasi Menyusui Dini (IMD) juga merupakan faktor 
penentu keberhasilan menyusui dan keberlangsungan menyusui selanjutnya.

\section{Ucapan Terimakasih}

Penulis mengucapkan terimakasih kepada Prodi S2 Kebidanan Universitas 'Aisyiyah Yogyakarta yang telah memfasilitasi serta memberikan bimbingan dalam penelitian ini.

\section{Daftar Pustaka}

A Karlstrom., H Lindgren. 2013. Maternal and infant outcome after caesarean section without recorded medical indication : finding from a swedish case-control study

Agboado G, Elaine Michel, Arpana Verma. 2010. Factors Associated with Breastfeeding cessation in Nursing Mother in Peer Support Programme in Eastern Lancashire. Journal BMC Pediatric

Alfianrisa A, Salimo H, and Pamungkasari EP. 2017. Factors Associated with Exclusive Breashfeeding: Application of PrecedeProceed and Theory of Planed Behavior. Journal of Maternal and Child Health, Vol. 2, No. 1, HIm. 42-53

Alves AL, Oliveira MI, and Moraes JR. 2013. Breashfeeding Friendly Primary Care Unit Initiative and the Relationship with Exclusive Breastfeeding. Revista de Saude Publica, Vol. 47, No. 6, HIm. 1030-1040

A Karlstrom., H Lindgren. 2013. Maternal and infant outcome after caesarean section without recorded medical indication : finding from a swedish case-control study. Journal International Obstetri and Gynecology.

Atika Z, Salimo H, and Dewi YLR. 2018. Multilevel Analysis on the Determinants on Exclusive Breashfeeding at Gunung Anyar Community Health Center, Surabaya, Indonesia. Journal of Maternal and Child Health, Vol. 3, No. 3, HIm. 176-183

Arini H. 2012. Mengapa Seorang Ibu Harus Menyusui. Yogyakarta: Flashbook
Arksey H, O'Malley L. Scoping studies: towards a methodological framework. Int J Soc Res Methodol 2005;8(1): 19-32.

Astuti AW and Rosmary M. Intervention Analysis of Addressing Exclusive Breastfeeding (EBF) Barriers to Improve EBF Coverage Among Industrial Woman Employees in Indonesia. Journal of Health Technology Assesment in Midwifery. Vol.1 No.1: 1-16

Bettani-Saltikov, J. 2012. How to do a systematic literature review in nursing : a step-by-step guide. Maidenhead: McGraw-Hill/Open University Press

Bodner K, Wierrani F, Grunberger W, and Adler BB. 2011. Influence of the Mode of Delivery on Maternal and Neonatal Outcomes: A Comparison Between Elective Caesarean Section and Planned Vaginal Delivery in a Low-Risk Obstetric Popupation. Chaplin, J., Kelly, J., Kildea, S., 2016. Maternal perceptions of breastfeeding difficulty after caesarean section with regional anaesthesia: A qualitative study. Women Birth J. Aust. Coll. Midwives

Chaplin, J., Kelly, J., Kildea, S., 2016. Maternal perceptions of breastfeeding difficulty after caesarean section with regional anaesthesia: A qualitative study. Women Birth J. Aust. Coll. Midwives 29, 144-152.

Dachew BA, and Bifftu BB. 2014. Breastfeeding Practice and Associated Factors Among Female Nurses and Midwives at North Gondar Zone, Northwest Ethiopia: A CrosSectional Institution Based Study. International Breastfeeding Journal, Vol. 9

David Mukunya, James K Tumwine, Victoria Nankabirwa. 2017. Factors associated with delayed initiation of breastfeeding. Global Health Action, 10:1

El-Houfey AA, Saad K, Abbas AM, Mahmoud SR, and Wadani M. 2017. Factors That Influence Exclusive Breastfeeding: A Literature Review. International Journal of Nursing Didastics, Vol. 7, No. 5

Elyas L, Mekasha A, Admasie A, and Assefa E. 2017. Exclusive Breashfeeding Practice and Associated Factors Among Mother Attending Private Pediatric and Child Clinics, Addis Ababa, Ethipia: A Cross Sectional Study. International Journal of Pediatrics 
Fern R. Hauck, John M. D. Thompson, Kawai O. Tanabe, Rachel Y. 2011. Breastfeeding and Reduce Risk of Sudden Infant Death Syndrom : A Meta-analysis. Journal American Academy of Pediatrics

Gabriel Agboado, Elaine Michel, Arpana Verma. 2010. Factors Associated with Breastfeeding cessation in Nursing Mother in Peer Support Programme in Eastern Lancashire. Journal BMC Pediatric

Hung KJ, and Berg O. 2011. Early Skin to Skin After Cesarean to Improve Breashfeeding. American Journal Maternal Child Nursing, Vol. 36, No. 5

Ikatan Dokter Anak Indonesia. 2010. Indonesia Menyusui. Jakarta. Badan Penerbit IDAI

Ikatan Dokter Anak Indonesia (IDAI). Indonesia Pediatric Society. Nilai Nutrisi Air Susu Ibu 2013.

Kiani, S.N., Rich, K.M., Herkert, D., Safon, C., PérezEscamilla, R., 2018. Delivery mode and breastfeeding outcomes among new mothers in Nicaragua. Matern. Child. Nutr. 14.

Kitano N, Nomura K, Kido M, Murakami K, Ohtubo T, Ueno M, and Sugimoto M. 2016. Combined Effects of Maternal Age and Parity on Successful Initiation Ofexclusive Breastfeeding. Journal of Preventive Medicine Report 3, HIm. 121-126

Koopman, I., Callaghan-Koru, J.A., Alaofin, O., Argani, C.H., Farzin, A., 2016. Early skin-toskin contact for healthy full-term infants after vaginal and caesarean delivery: a qualitative study on clinician perspectives. J. Clin. Nurs. 25, 1367-1376.

Kumar VRH, Jahagirdar SM, and Ravishankar M. 2014. Study of Patient Satisfaction and Self=Expressed Problems After Emergency Caesarean Delivery Under Subarachnoid Block. Indian Journal of Anaesthesia, Vol. 58, No. 2, HIm. 149-153

Lestari E, Pamungkasari EP, and Dewi YLR. 2019. Multilevel Analysis on the Contextual Effect of Posyandu on Exclusive Breastfeeding in Sleman, Yogyakarta. Journal of Maternal and Child Health, Vol. 4, No. 4, HIm. 250-259

Levac Danielle, Heather Colquhoun and Kelly $\mathrm{K}$ 2010. Scoping Studies : advancing the methodology.
Ly Thi Hai Ngo, Hsueh-Fen Chou, Meeling. 2018. Breastfeeding Self Efficacy and Related Factors in Postpartum. An International Journal Midwifery

Maastrup R, Hansen BM, Kronborg $\mathrm{H}$, Bojesen SN, Hallum K, Frandsen A, Kyhnaeb A, Svarrer I, and Hallstrom I. 2014. Factors Associated with Exclusive Breashfeeding of Preterm Infants: Result from Prespective National Cohort Study. PLOS ONE, Vol. 9, No. 2

Mannion CA, Hobbs AJ, McDonald SW, and Tough SC. 2013. Maternal Perceptions of Partner Support during Breastfeeding. International Breastfeeding Journal, Vol. 8, No. 4

Nisa J, Salimo H, and Budihastuti UR. 2017. Factor Nickerson, E Lauren et al. 2012. Mother's Experience of Father's Support for Breastfeeding. Journal Public Health Nutrition, Vol 9, No.15, HIm 1780-1787

Socio Demoghrapy and Obstetric that Influence the Timliness of Early Breashfeeding in Tegal Regency. Journal of Maternal and Child Health, Vol. 2, No. 2, HIm. 89-99

Pham, M.T., Rajić, A., Greig, J.D., Sargeant, J.M., Papadopoulos, A., McEwen, S.A., 2014. A scoping review of scoping reviews: advancing the approach and enhancing the consistency. Res. Synth. Methods5, 371385. https://doi.org/10.1002/jrsm.1123

Peters, J.P.M., Hooft, L., Grolman, W., Stegeman, I., 2015. Reporting Quality of Systematic Reviews and Meta-Analyses of Otorhinolaryngologic Articles Based on the PRISMA Statement. PLoS ONE 10.

Sandra Fikawati. Ahmad. 2009. Penyebab Keberhasilan dan Kegagalan Praktik Pemberian ASI Eksklusif. Jurnal Kesehatan Masyarakat Nasional Vol.4 No.3

Senarath U, Siriwardena I, Godagandage SSP, Jayawickrama H, Fernando DN, and Dibley MJ. Determinants of Breashfeeding Practices: An Analysis of the Sri Lanka Demoghrapic and Health Survey 2006-2007. Journal of Maternal and Child Nutrition, Vol 8 , No. 3

Sharma IK, and Byrne A. 2016. Early Initiation of Breashfeeding: A Systematic Literature Review of Factors and Barriers in Shouth Asia. International Breashfeeding Journal, Vol. 11, No. 17

Sinta $\mathrm{P}$, Salimo $\mathrm{H}$, and Pamungkasari EP. Multilevel Analysis on the Biosocial and Economic 
Determinants of Exclusive Breastfeeding. Journal of Maternal and Child Health, Vol. 2, No. 4, HIm. 356-370

Thobeka P Jikijela et al., 2018. Caesarean Section Deliveries : Experience of Mother of Midwifery Care at Public Hospital in Nelson Mandela Bay Journal.

Tokat, M.A., Serçekuş, P., Yenal, K., Okumuş, H., 2015. Early Postpartum Breast-Feeding Outcomes and Breast-Feeding Self-Efficacy in Turkish Mothers Undergoing Vaginal Birth or Cesarean Birth With Different Types of Anesthesia. Int. J. Nurs. Knowl. 26, 73-79. https://doi.org/10.1111/2047-3095.12037

Tricco, A.C., Lillie, E., Zarin., O’Brien., 2016. A scoping review on the conduct and reporting of scoping review. BMC Med. Res. Methodol. 16
Wardani EK, Hastuti URB, and Adriyani RB. 2017. Relationship between Sociodemographic Factors and Mother's Participation in Breast Feeding Support Group with Exclusive Breastfeeding Success in Banyuwangi. Journal of Maternal and Child, Vol. 2, No. 4, HIm. 335-344

WHO. 2018. Exclusive Breastfeeding For Optimal Growth, Development And Health Of Infants.

Zanardo, V., Svegliado, G., Cavallin, F., Giustardi, A., Cosmi, E., Litta, P., Trevisanuto, D., 2010. Elective Cesarean Delivery: Does It Have a Negative Effect on Breastfeeding? Birth 37, 275-279. https://doi.org/10.1111/j.1523536X.2010.00421.X 